\title{
About Strengthening and Improving the Study on Bilingual Teaching of College Undergraduates
}

\author{
Shanshan XU \\ School of Economics and Management, Shenyang Aerospace University, \\ Shenyang 110136, China \\ E-mail: susan_xuss@hotmail.com
}

Keywords: Strengthen and improve, Undergraduate students, Bilingual teaching, Mode study

\begin{abstract}
Bilingual teaching is an important attempt to teaching reform of China's higher education in the context of economic globalization, and also an important goal for culturing international and innovative talents. Under such new situation, colleges shall further enhance the awareness about the necessity of bilingual teaching on undergraduate students, make clear the nature, purpose and mission of bilingual teaching, strengthen and improve the systematic study of bilingual teaching mode, and effectively improve the quality and talent training of bilingual teaching, so that bilingual teaching can be continuously explore and improved during the practice of course formation.
\end{abstract}

Bilingual teaching is an important attempt to teaching reform of China's colleges in the context of economic globalization. With the rapid development of economic globalization, China's higher education has been gradually shifting from elite education to mass education, and also to international trend. The culturing of international and innovative talents has become one important goal of higher education, because it may affect national prosperity and national cultural renaissance. Bilingual education as a means of teaching the micro level, and to achieve this goal are closely linked. Bilingual teaching, as a micro teaching, has a direct link to this goal.

I. Bilingual teaching for college undergraduates has made substantial achievements

Ministry of Education (MOE) pays much attention on bilingual teaching in colleges and universities. In 2001 the Ministry of Education issued "Opinions on Strengthening Undergraduate Education to Improve the Quality of Teaching", which proposes the requirement that "undergraduate education shall create conditions for teaching open courses and specialized courses in English and other foreign languages". In 2002 for the first time, the Ministry of Education defined bilingual education as: foreign language teaching materials are used and lessons taken in foreign language accounts for more than $50 \%$ of the whole course hours. In 2007 the Ministry of Education issued the "Opinions on Further Deepening the Reform of Undergraduate Teaching to Comprehensively Improve the Quality of Teaching", which also made it clear on "promoting bilingual teaching courses and exploring effective teaching methods and modes, to effectively improve college students' English level and ability to directly use English in scientific research".

In recent years, to implement the MOE' deployment and comments regarding the bilingual teaching in colleges, bilingual teaching has been generally carried out in colleges all over the country, and exploration about bilingual teaching has been conducted in many disciplines, particularly the teaching for college undergraduates, gaining some teaching experience and some substantial results. We can see the following advantages of bilingual teaching: (1) Bilingual teaching improves students' professional skills by helping them learn technical terms of their own fields and improve their ability to retrieve and read professional articles. (2) Bilingual teaching creates an English atmosphere for students. (3) Bilingual 
teaching raises students' overall quality by helping them broaden their international perspective and establish a sense of international exchange. (4) A team of bilingual teachers with a master's degree or overseas experience is initially formed, laying the foundation for bilingual teaching of colleges.

\section{Main problems for current bilingual teaching mode}

Although bilingual teaching has been carried out in colleges since nearly a decade ago, there are still some practical problems, mainly in the following areas:

1. Students have poor master of English, especially in listening and speaking ability. Students find it difficult to understand and exchange with teachers during the class, leading to low learning efficiency and heavy burden. Students all think their incompetence in bilingual courses as the biggest problem, but the higher the grade they are, the less restriction from English they will face.

2. Curriculum system is not perfect. Relatively simple types of bilingual teaching courses and nonsystematic bilingual teaching are great barriers to raise students' professional and cultural quality in the talent culturing process. Meanwhile, the lack of college application and practice courses is not conducive to the training of compound talents, unable to meet the requirements for personnel under the trend of economic globalization.

3. Teaching methods are not advanced enough. Traditional teaching and testing methods constrain bilingual teaching, and hinder students to take the initiative. Students' course grade is still tested by exam papers, and as an inevitable result, teachers simply teach by reading through teaching material, while students have to learn by rote, lack of opportunities to use their brains and innovation ability.

4. The lack of bilingual teaching faculty is a great problem in bilingual teaching. Such problem is caused by severe requirements for teachers by bilingual courses, including pronunciation, fluency, expertise level, etc., which are not met by the current bilingual teachers.

5. Unified teaching standards, specifications and specific requirements have not been formed. Also, there are not enough systematic research and standard system for teaching evaluation, curriculum assessment and monitoring about bilingual teaching.

\section{Problems to be solved for further strengthening research on bilingual teaching modes}

Bilingual teaching is an important task of higher education when cultivating innovative talents for the future world. As a large country of education, China currently has more than 1,100 undergraduate colleges. Therefore, the research on bilingual teaching for university undergraduates will help promote systematic research on bilingual teaching mode of nationwide universities, so that bilingual teaching can be continuously explored and improved in practice of curriculum construction.

(a) Raise the understanding about necessity of bilingual teaching

English is the most important international language, but many of our students after ten years of learning English cannot read books English, even not hear or speak English, difficult to directly communicate with foreigners. Therefore, the most direct and most important starting point of bilingual teaching is to improve students' English proficiency and develop their potential in the professional field, thus train talents with international competitiveness and vision. In China, the meaning of bilingual teaching is generally known that teachers give classes by mainly using a foreign language (currently mostly English) rather than Chinese. It requires teachers to teach with correct and fluent English, but not to absolutely exclude the Chinese to avoid students' thinking lag due to language barriers.

(b) Make clear the nature, purpose and mission of bilingual teaching

Bilingual teaching is the basic lesson of a particular professional discipline in colleges. The purpose of the course: on the basis of the existing English level, students can be familiar with and master the common expressions of their own masters through reading relevant English literature. On the one hand, students shall raise their reading and translation capabilities, especially ability to read and translate English literature of their own masters correctly and quickly; On the other hand, students shall improve 
their English writing skills, so that they can independently write papers of their masters and get writing skills for English summary. After that, they can apply the language they have learned and write out general professional reports in accordance with professional practice and standardized format.

(c) Strengthen and improve the study of bilingual teaching mode for undergraduates

Teaching mode refers to a stable teaching framework and activity schedule built up under some teaching ideas or theories. As a structural framework, it reflects the overall teaching activities, the relationship between various elements and their features from the macro level. As the activity schedule, it should have stability and maneuverability. Optimization of bilingual teaching mode is the key to create a bilingual learning environment for students, to cultivate the ability to think in English, and change from passive learning to active learning. Therefore, the establishment and improvement of undergraduate bilingual education model, we need to put forward a modern educational management vision and ideas for solutions to this problem, and effectively improve the quality of teaching and training of bilingual personnel

1. We shall strengthen the propaganda of bilingual teaching, and enhance students' self-confidence. As a new way of teaching, bilingual teaching is different for students. Some students worry about that they cannot adapt to such teaching, which reflects that those students are still in the process of adaptation to bilingual teaching However, we can see from the teaching practice and integrated perspective that most students still have confidence to master professional English. This is because they have relatively good foundation in English and aids from teaching materials in Chinese. With the above-mentioned advantage and problem, we need to make greater efforts to publicize the new teaching method, and focus on students' psychological adjustment to reduce or relieve their worries, enabling them to better meet and adapt to bilingual teaching.

2. We shall set up bilingual courses from reality and based on the training of personnel. A qualified personnel should possess excellent professional qualities, which include the ability to use a second language in communication and expertise skills. Professional bilingual curriculum plays a decisive role in the training of professional quality. Therefore, we shall set bilingual curriculum based on the actual needs of personnel training, avoid setting courses particularly for someone. Since such professional foreign language is transformed from the traditional foreign language master, with weak professional construction of infrastructure and teaching team, probably only those courses teachers are familiar with can be given, which must be avoided. We shall not simply copy from the traditional foreign language master. Instead, we shall take into consideration the economic and social development and the school's actual situation to set bilingual curriculum and timely adjust teaching plan and syllabus of curriculum, so that bilingual teaching programs adequately reflect the dynamic frontier disciplines and professional development.

3. We change teaching methods and train students with practical abilities. The ultimate goal of education is to be applied to practice. Thus in the actual process of teaching we shall highlight the practice teaching, so that students can truly apply their knowledge they learn. Practice courses are an important part of the course architecture, and the construction of training bases inside and outside schools is the important carrier for practice teaching and practical classes. Therefore, colleges need to establish a complete set of practical teaching system. First of all, there must be a series of good practice facilities and venues, which are the material basis for practical teaching. At the same time, we must arrange practical activities for students, so that students can go out of schools, break the boundaries between books and reality, and finally complete the transition "from the school to the market,", meeting the requirements for graduates in engineering practice capability from front-line positions in social production and management. 
4. We shall integrate and introduce bilingual teaching resources to give students international vision. With the arrival of the one-world economy and the information era, for training of personnel, we must pay attention to the integration and introduction of high-quality teaching resources to develop an international perspective of students. In the teaching process we need to take full advantages of modern education technology and network resources at home and abroad, create innovative electronic information resources, expand and extend the teaching materials, so that students have enough space for creativity. Universities with enough power should also actively take full advantages of opportunities for foreign joint schools, and actively carry out foreign internship base, thus realizing the thinking match between world-class enterprises and college personnel training.

5. We shall form the evaluation system for the development of bilingual teaching. To do this we shall gradually form a unified set of bilingual teaching standards, specifications and specific requirements, establish systematic research about bilingual teaching adapting to the further development of bilingual teaching, and build up a standardized evaluation, curriculum assessment and monitoring system of bilingual teaching to ensure institutionally healthy development of bilingual teaching.

6. We shall strengthen and enrich the faculty team and promote the construction of bilingual teachers. Bilingual teaching puts forward higher requirements for teachers, such as the ability to master the frontier knowledge, a thorough understanding of the curriculum, ability to control the overall structure of the course, rich experience in scientific research, an international perspective, ability to combine scientific research results with curriculum, and the ability to use the English language. Currently, the university bilingual teachers come from three main sources: (1) teachers of linguistics or literature, with high level of basic English but low level of knowledge about professional courses; (2) teachers with professional background, but probably low level of foreign language; (3) teachers with overseas background. Those teachers have nice performance both in language and professionals, and will bring good teaching effects and vivid class atmosphere, but in a relatively small number.

Therefore, universities should culture bilingual teachers from these three sources, and make full use of them to form a complementary. if possible, we shall send teachers from the first two sources abroad for research cooperation, academic exchanges and refresher training, so that they can timely get access to cutting-edge disciplines, grasp the academic development of the curriculum, thereby providing assurance for strengthening and improving bilingual teaching of college undergraduate students, deepening teaching and educational reform, and effectively improving the quality of teaching and training of personnel.

\section{References}

[1] H.Chen, MY.Chen, NJ.Chen, “Undergraduate's Adaptability to Bilingual Teaching and Countermeasures: Four-Year Longitudinal Studies”, Modern Education Management, pp.80-82, 2010 (1)

[2] J.Chen, XM.Wang, "Innovative Education Applied In College English Teaching”, Union Forum, pp.128 - 129, 2009 (3)

[3] LZ.Mao, Y.Wang, "Comparative Study of Self-Study Via Listening \& Speaking Network and Classroom Teaching of College English”, Shenyang Agricultural University Journal, pp.588-591 2012

[4] JH.Sun, YG.Cui, "Research on Countermeasures and Trend of Training High-Quality Foreign Language Talents in Universities”, Liaoning Normal University Journal, pp. 69-72, 2010 (5)

[5] XH.Zhu, ZhD.Zhao, "Research on Training Mode of Dual Foreign Language Talents", Modern Education And Management, pp.74-76, 2010 (4). 